\title{
Performance and economic viability of tambaqui, Colossoma macropomum, selectively bred for weight gain
} \author{
Márcio Aquio HOSHIBA ${ }^{3}$, Janessa Sampaio de ABREU ${ }^{3}$ \\ Universidade Federal de Mato Grosso do Sul, Faculdade de Medicina Veterinária e Zootecnia, Campo Grande, MS, Brazil \\ 2 Universidade Estadual de Mato Grosso, Pontes e Lacerda, MT, Brazil \\ 3 Universidade Federal de Mato Grosso, Faculdade de Agronomia e Zootecnia, Cuiabá, MT, Brazil \\ ${ }^{4}$ Delicious Fish Agroindústria e Comércio de Pescados LTDA, Cuiabá, MT, Brazil \\ * Corresponding author: zootec.carla@gmail.com; (D) https://orcid.org/0000-0002-7311-1452
}

Ana Carla Carvalho SILVA ${ }^{1 *}$, Adriana Fernandes de BARROS², Flávia Maria Fernandes MENDONÇA ${ }^{3}$, Kamyla Fernanda da Silva GAMA ${ }^{3}$, Rebeca MARCOS ${ }^{1}$, Jayme Aparecido POVH ${ }^{1}$, Darci Carlos FORNARI ${ }^{4}$,

\begin{abstract}
Tambaqui, Colossoma macropomum, is one of the most produced species in Brazilian fish farming, which has boosted the development of new technologies to increase its productivity. The aim of this study was to evaluate production performance in two second-generation tambaqui stocks selectively bred for weight gain in a semi-intensive rearing system and assess its influence on total production cost. We analyzed 300 fish (initial mean weight and standard length of $160 \mathrm{~g}$ and $17 \mathrm{~cm}$, respectively) of two families (A and B, 150 fish each). The fish were individually marked with microchips and stocked in an $800-\mathrm{m}^{2}$ excavated pond. For economic analysis, the obtained performance data were extrapolated for a fish farm with a 10-ha pond, adopting the Total Production Cost methodology. After 270 days of farming, the fish from family B were significantly superior ( $\mathrm{p}<$ 0.05 ) for all analyzed performance parameters (final weight $=1965.0 \mathrm{~g}$; weight gain = $1786.7 \mathrm{~g}$; biomass gain = 255.2 kg) and morphometric growth in relation to the fish from family A (final weight $=1881.0 \mathrm{~g}$; weight gain $=1737.5 \mathrm{~g}$; biomass gain: $217.7 \mathrm{~kg}$ ). The total production cost estimations indicated that fish from family B would allow for a $4 \%$ reduction in the average fixed cost and a $1 \%$ decrease in the total average production cost.
\end{abstract}

KEYWORDS: aquaculture productivity, breeding, fish farming, production cost, native Brazilian fish

\section{Desempenho e viabilidade econômica da produção do tambaqui, Colossoma macropomum melhorado geneticamente para ganho de peso}

\section{RESUMO}

O tambaqui, Colossoma macropomum, é uma das espécies mais produzidas na piscicultura brasileira, o que tem impulsionado o desenvolvimento de novas tecnologias para aumentar sua produtividade. O objetivo deste estudo foi avaliar o desempenho da produção de dois estoques de tambaqui de segunda geração melhorada geneticamente para ganho de peso em um sistema de criaçáo semi-intensivo, e avaliar sua influência no custo total de produção. Foram analisados 300 peixes (peso e comprimento padrão inicial médio de $160 \mathrm{~g}$ e $17 \mathrm{~cm}$, respectivamente) de duas famílias (A e B, 150 peixes cada). Os peixes foram marcados individualmente com microchips e estocados em um tanque escavado de $800 \mathrm{~m}^{2}$. Para análise econômica, os dados de desempenho obtidos foram extrapolados para uma piscicultura com 10 ha de lâmina d'água, adotando a metodologia Custo Total de Produção. Depois de 270 dias de cultivo, os peixes da família B foram significativamente superiores $(\mathrm{p}<0,05)$ para todos os parâmetros de desempenho analisados (peso final = 1965,0 g; ganho de peso = 1786,7 g; ganho de biomassa = 255,2 $\mathrm{kg}$ ) e crescimento morfométrico em relação aos peixes da família A (peso final = 1881,0 g; ganho de peso = 1737,5 g; ganho de biomassa: $217,7 \mathrm{~kg}$ ). As estimativas de custo total de produção indicaram que os peixes da família B permitiriam uma redução de $4 \%$ no custo fixo médio e uma redução de $1 \%$ no custo médio total de produção.

PALAVRAS-CHAVE: custo de produção, melhoramento genético, peixe nativo brasileiro, piscicultura, produtividade aquícola

CITE AS: Silva, A.C.C.; Barros, A.F.; Mendonça, F.M.F.; Gama, K.F.S.; Marcos, R.; Povh, J.A.; Fornari, D.C.; Hoshiba, M.A.; Abreu, J.S. 2020. Performance and economic viability of tambaqui, Colossoma macropomum, selectively bred for weight gain. Acta Amazonica 50: 108-114. 


\section{INTRODUCTION}

The world fish production reached around 171 million tons in 2016 , and $47 \%$ of this total were represented by the aquaculture segment (FAO 2018). To meet the increasing demand for animal protein for hundreds of millions of people around the world, strategies must be developed that maximize productivity per area while reducing costs and increasing profitability. In this scenario, the use of genetically superior animals, which are selected based on their production performance, may increase the efficiency of aquaculture production (Oliveira et al. 2012; Marcos et al. 2016; Silva et al. 2018).

The implementation of breeding programs for terrestrial animals and plants has considerably contributed to increasing production indices, but few aquatic animals have undergone a selective breeding process (Nguyen 2016; Silva et al. 2018). A breeding program for Atlantic salmon (Salmo salar Linnaeus 1778) was developed in the 1970s in Norway and later in 1998 in Canada. Both programs aimed at increased growth rates and carcass quality (Hilsdorf and Orfăo 2011; Silva et al. 2018). In Asia, consolidated selective-breeding programs exist for carp (Cyprinus sp), Nile tilapia (Oreochromis niloticus Linnaeus 1758) and giant freshwater prawn (Macrobrachium rosenbergii De Man 1897) (Nguyen 2016). In Brazil, selective breeding programs for fish have been developed with Nile tilapia (Oliveira et al. 2012), but initiatives for native species still have very little impact on commercial fish farming (Silva et al. 2018).

A selective breeding program for the Amazonian native species tambaqui, Colossoma macropomum Cuvier 1818 (Characidae) was implemented in 2008 by the Aquabrasil project, coordinated by the Brazilian Agricultural Research Corporation (EMBRAPA) (Resende 2009). Tambaqui is the most widely farmed native fish in Brazil (IBGE 2020). The species is characterized by satisfactory production performance, high yield potential, effective feed utilization and tolerance to low dissolved oxygen levels, in addition to having social and economic importance (Brabo et al. 2017; Gomes et al. 2018). Although the program was terminated in 2012, it has led to new initiatives regarding breeding programs for this species, mainly by the private sector (Silva et al. 2018).

Our purpose with this study was to examine the performance of second-generation tambaqui selectively bred for weight gain, originating from the Aquabrasil project, as well as to evaluate the influence of production performance parameters on the economic indicators of an average-size Brazilian commercial fish farm operating with a semi-intensive culture system.

\section{MATERIAL AND METHODS}

\section{Study site}

The study was conducted in the fish farming unit of the Faculty of Agronomy and Animal Science (FAAZ) of Universidade Federal de Mato Grosso (UFMT) in Cuiabá, Brazil (15 $\left.51^{\prime} 56^{\prime \prime} \mathrm{S}, 56^{\circ} 04^{\prime} 36^{\prime \prime} \mathrm{W}\right)$. All experimental procedures were approved by the Ethics Committee on Animal Use (CEUA) of UFMT (authorization no. 23108.069114/2014-85).

\section{Selected animals}

In April 2015, male and female tambaqui breeders from the first selectively bred generation (F1) were selected at a private fish farm associated with the breeding program

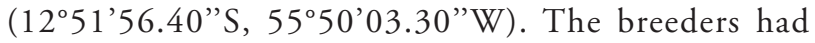
different AGV for weight gain and were subjected to induced reproduction with carp pituitary extract, following the protocol described by Woynarovich and Horvath (1983). F1 males and females were crossed to generate two families: family $\mathrm{A}$ (genetic value $=38.5$ ) and family B (genetic value = 42.9), which constituted the treatments in the present study.

\section{Experimental conditions}

The post-larvae (uniform age) were transported to the fish farming station at UFMT and stocked in net cages of $15 \mathrm{~m}^{3}$ (one cage per family). Subsequently, 300 fish (150 of each family) were selected from homogeneous lots by size (initial weight and standard length within a $\pm 10 \%$ range of the mean values of $160 \mathrm{~g}$ and $17 \mathrm{~cm}$, respectively), individually identified with a microchip (AnimallTAG) inserted in the back musculature and transferred in October 2015 to an excavated open-air pond $\left(800 \mathrm{~m}^{3}\right)$ on sandy-clayey, hydromorphic, alluvial soil. The pond had been previously sanitized with lime $\left(50 \mathrm{~g} \mathrm{~m}^{-2}\right)$, followed by liming with dolomitic limestone (100 $\mathrm{g}$ $\left.\mathrm{m}^{-2}\right)$ and fertilization with rice bran $\left(25 \mathrm{~g} \mathrm{~m}^{-2}\right)$, ammonium sulfate $\left(7.5 \mathrm{~g} \mathrm{~m}^{-2}\right)$ and single superphosphate $\left(2.5 \mathrm{~g} \mathrm{~m}^{-2}\right)$.

The experiment began in November 2015, after an acclimation period. Fish growth was evaluated monthly, over the course of 270 days, through biometric measurements. The first measurements were performed in December 2015 and the last in 2016. Eight biometric-measurement events were carried out in total. No measurements were taken in June 2016, when cold fronts that hit the region and caused water temperature to drop below the thermal comfort zone of tambaqui (26-32 ${ }^{\circ}$ C) (Boyd 1998; Menezes 2005; Gomes et al. 2018), and we decided not to cause additional stress to the fish through the biometry process. Prior to the biometric measurements, the fish were feed-deprived for $12 \mathrm{~h}$ and then anesthetized with eugenol (50 $\left.\mathrm{mg} \mathrm{L}^{-1}\right)$ (Inoue et al. 2011). Subsequently, all fish were captured with trawl nets and weighed on a 5 -g precision digital scale (Toledo 9094).

The final stocking density (August 2016) was $0.75 \mathrm{~kg} \mathrm{~m}^{2}$, characterizing a semi-intensive production system, which is 
a frequently used culture system on fish farms across Brazil, especially in Mato Grosso State. Fish farmers in the region typically make use of rainwater, with low water renewal and, consequently, decreased oxygenation and stocking rates in the cultivation spaces (IMEA 2014). Throughout the experiment, water was renewed in the pond only in the rainy season (March to February), which characterizes a low-exchange system without supplemental aeration.

Throughout the experiment, the fish received an extruded commercial feed (VB Alimentos-Cardume) (6\% ether extract, $32 \%$ crude protein, $3 \%$ fibrous matter and $10 \%$ mineral matter). Feed was delivered twice daily. The feeding rate ranged from $8 \%$ (initial phase) to $1 \%$ (final phase). The average live weight of the fish from each family was adjusted according to the monthly biometry and the observation of intake. Feed supply was interrupted if the fish would stop consuming it while being delivered.

The following physicochemical variables were measured weekly for the pond water: temperature and dissolved oxygen (Q400BC, Quimis'), alkalinity (methyl orange indicator solution) and non-ionized ammonia (Alcon Labcon test kits) (Emerson et al.1975).

\section{Performance analyses}

The evaluation period began at the end of spring and ended in mid-winter, comprising climatic variations that included rainy months with high temperatures (January, February and March) and drier months with lower temperatures (April, May and June). At the end of the experimental period, the fish were weighed and the following variables were measured (using a fish-measuring board, a tape measure and a caliper): total length (TL), from the anterior extremity of the head to the insertion of the caudal fin; head size (HS), from the anterior extremity of the head to the caudal border of the operculum; body height $(\mathrm{BH})$, measured transversely in the highest region of the body (at the 1st ray of the dorsal fin); body width (BW), measured at the 1st ray of the dorsal fin; and body circumference (BC), measured at the 1st ray of the dorsal fin.

The daily weight gain (DWG) of each family was calculated monthly from January 2016 and expressed in $\mathrm{g} \mathrm{day}^{-1}$, as follows: DWG $=$ (average monthly weight - average weight previous month) / $\mathrm{N}$ days since previous month weighing. The additional performance traits were also determined for each family at the end of the experimental period: Weight gain $(\mathrm{g})=$ average final weight - average initial weight; Final biomass $(\mathrm{kg})=$ average final weight $\mathrm{x}$ final number of fish / 1000; Specific growth rate $(\%)=\{[\operatorname{Ln}$ (average final weight) - Ln (average initial weight)/period in days] $\times 100$; Survival rate $(\%)=($ final number of fish $/$ initial number of fish $) \times$ 100; Apparent feed conversion $=$ amount of feed consumed in the period/biomass gain in the period. The last variable was considered jointly for both families, since they were reared in the same pond.

\section{Economic analysis}

An economic projection analysis was undertaken to determine the production costs of each family (A and B), where the performance data obtained at the end of the experiment (August 2016) were extrapolated for an existing commercial fish farm with a 10-ha pond in a semi-intensive production system in the state of Mato Grosso, Brazil. We used actual values of the investments made by this fish farm in support infrastructure, construction of excavated ponds, acquisition of land, machinery and materials and environmental licensing.

The amount invested in fish farming was calculated by the Total Cost Methodology described by Martin et al. (1998), with market values corresponding to January 2020, considering the exchange rate of the Brazilian Real (BRL) as $1 \mathrm{USD}=4.35 \mathrm{BRL}$ for conversion purposes. The total production cost is a more appropriate index in this type of economic projection, as it involves all production factors, representing the sum of variable and fixed costs. Variable costs consist of expenditures on hired labor, feeding, fuel, electrical energy, juveniles, general inputs, occasional expenditures, fees and taxes, maintenance of machinery, return on working capital and family labor. Fixed costs are composed of depreciation and the costs of land opportunity, manager and fixed capital.

To calculate the economic indicators and determine the total production cost, we included the following production parameters for families A and B obtained at the end of the experimental period: final average weight $(\mathrm{kg})$, stocking biomass (kg), survival rate (\%) and rearing cycle (months). Based on these data, values of other performance variables necessary for the economic projection were simulated for both families, such as initial number of fish (n), final number of fish (n) and total production $(\mathrm{kg})$, which were then extrapolated for a commercial fish farm with a 10-ha pond. The average production cost $(\mathrm{AC})$ was calculated as follows: $\mathrm{AC}=$ Costs / $\mathrm{Q}$, where $\mathrm{AC}$ is the ratio between the costs (variable, fixed and total costs) and the quantity (Q) of fish produced (total weight in $\mathrm{kg}$ ) for a 10-month cultivation period (corresponding to one month acclimation plus 270 days experimental period in our study). Results were expressed in BRL kg-1.

A sensitivity analysis (Hamby 1994) was conducted to determine the impact of variations in the most influential factors of the culture system on the results. Scenarios were simulated for the family with superior performance in order to measure its influence on economic indicators. 


\section{Statistical analysis}

The experiment followed a completely randomized design, with two treatments (families A and B) and 150 replicates. Each fish was considered a replicate. Production performance variables (final weight, final biomass, weight gain, biomass gain and specific growth rate) and morphometric variables were subjected to the Shapiro-Wilk normality test and the Levene test for homogeneity of variance. As all variables met these assumptions, they were analyzed by one-way analysis of variance (ANOVA) using SAS (Statistical Analysis System) software. Daily weight gain (DWG) was analyzed separately in each month. Differences between the families were considered significant at $\mathrm{p}<0.05$.

\section{RESULTS}

All physicochemical variables remained within the range recommended for tropical fish production by Boyd (1998), except dissolved oxygen in January and February. The water temperature was adequate during most part of the experimental period, except in the winter (June), when it was below ideal, which would be between 26 and $29^{\circ} \mathrm{C}$ (Boyd 1998). Although this result may have affected performance in winter, it should be emphasized that the effect was the same for both families, considering that both were in the same pond (Figure 1). Daily weight gain was significantly higher for family B in January and July (Figure 1). The lowest DWGs for both families were obtained from April to July, the coolest months of the study period, while the highest DWGs (11.26 and $10.84 \mathrm{~g} \mathrm{day}^{-1}$ for families $\mathrm{A}$ and $\mathrm{B}$, respectively) were

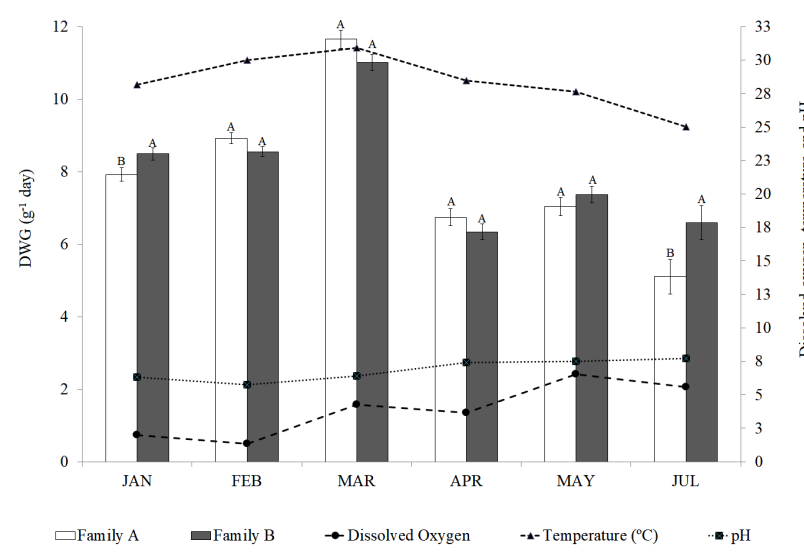

Figure 1. Average monthly daily weight gain (DWG) during the cultivation of tambaqui, Colossoma macropomum from the second generation of two families selectively bred for weight gain. Distinct letters above each pair of columns indicate significant differences $(p<0.05)$ between families within the month (year 2016). The dashed lines represent the monthly average dissolved oxygen, temperature and $\mathrm{pH}$ values of the water in the cultivation pond. observed in March, when the highest water temperature was recorded (average of $30.9^{\circ} \mathrm{C}$ ).

At the end of the 270 days of cultivation, apparent feed conversion ratio was 1.86:1. Except for specific growth rate, all production performance parameters were significantly higher for family B than family A (Table 1). Survival rate was $90 \%$ for family B and $80.4 \%$ for family A. Final biomass was 239.7 and $283.9 \mathrm{~kg}$ for family A anb B, respectively. With the exception of head size and body width, all other morphometric parameters were significantly larger for family B than family A (Table 1).

The economic projection analysis indicated that family B has greater economic viability in the farming system tested, allowing $4 \%$ lower average fixed costs and $1 \%$ lower average total costs (Table 2). Because the fish from family B exhibited an overall significantly better performance than those from family A, with a $4.5 \%$ higher final average weight, sensitivity analysis was performed only for the stock of fish from family B. As our results indicate that fish from family B can reach slaughter weight earlier and with higher performance values

Table 1. Production performance and morphometric growth of tambaqui Colossoma macropomum, from the second generation of two families selectively bred for weight gain at the end of 270 days in a semi-intensive system. Values are the mean \pm standard error. The column "P-value" indicates the significance leve of the comparisons between families by ANOVA.

\begin{tabular}{lccc}
\hline & Family A & Family B & P-value \\
\hline Final weight $(\mathrm{g})$ & $1881.0 \pm 23.7$ & $1965.0 \pm 21.8$ & 0.0096 \\
Weight gain $(\mathrm{g})$ & $1737.5 \pm 22.7$ & $1786.7 \pm 21.3$ & 0.1162 \\
Specific growth rate $(\%)$ & $5.5 \pm 0.0$ & $5.4 \pm 0.0$ & $<0.0001$ \\
Total length $(\mathrm{cm})$ & $44.5 \pm 0.2$ & $44.9 \pm 0.1$ & 0.0286 \\
Standard length $(\mathrm{cm})$ & $36.8 \pm 0.1$ & $37.2 \pm 0.1$ & 0.0128 \\
Head size $(\mathrm{cm})$ & $10.4 \pm 0.0$ & $10.5 \pm 0.0$ & 0.1215 \\
Body width $(\mathrm{cm})$ & $4.8 \pm 0.0$ & $4.9 \pm 0.0$ & 0.0785 \\
Body height $(\mathrm{cm})$ & $16.5 \pm 0.1$ & $16.8 \pm 0.1$ & 0.0131 \\
Body circumference $(\mathrm{cm})$ & $38.5 \pm 0.2$ & $39.2 \pm 0.2$ & 0.0021 \\
\hline
\end{tabular}

Table 2. Productive and economic indicators of fish farming for two tambaqui, Colossoma macropomum, families selectively bred for weight gain on a fish farm with a 10 ha-pond (5-ha pond area per family) (average sale price: USD $5.00 \mathrm{~kg}^{-1}$; values in Brazilian Real as of January 2020; exchange rate: USD $1=$ BRL 4.35).

\begin{tabular}{|c|c|c|}
\hline Production indicator & Family A & Family B \\
\hline Production $(\mathrm{kg})$ & 32,056 & 33,302 \\
\hline Initial number of fish (n) & 21,234 & 18,830 \\
\hline Final number of fish (n) & 17,042 & 16,948 \\
\hline Average final weight (kg) & 1.881 & 1.965 \\
\hline Final stocking biomass (kg m²) & 0.641 & 0.666 \\
\hline Survival rate (\%) & 80.3 & 90.0 \\
\hline Production cycle (month) & 10 & 10 \\
\hline \multicolumn{3}{|l|}{ Economic indicator } \\
\hline Average variable cost (BRL kg-1) & 5.72 & 5.68 \\
\hline Average fixed cost (BRL kg $\left.{ }^{-1}\right)$ & 0.71 & 0.69 \\
\hline Average total cost $\left(\mathrm{BRL} \mathrm{kg}^{-1}\right)$ & 6.44 & 6.37 \\
\hline
\end{tabular}


Table 3. Results of simulations of sensitivity analysis with potential production-performance and economic indicators for the farming of the better-performing (according to a 270-day trial) of two families of tambaqui, Colossoma macropomum, selectively bred for weight gain. Simulations are projections for a fish farm with a 10-ha pond. Values in Brazilian Real as of January 2020 (USD 1 = BRL 4.35). AFW: average final weight; SR: survival rate; SB: stocking biomass; AFC: average fixed cost; ATC: average total cost. "Initial project status" corresponds to the parameter values of the 270-day trial.

\begin{tabular}{|c|c|c|c|c|c|}
\hline Family B & $\begin{array}{l}\text { AFW } \\
(\mathrm{kg})\end{array}$ & $\begin{array}{l}\text { SR } \\
(\%)\end{array}$ & $\begin{array}{c}\mathrm{SB} \\
\left(\mathrm{kg} \mathrm{m}^{2}\right)\end{array}$ & $\begin{array}{c}\mathrm{AFC} \\
\left(\mathrm{BRL} \mathrm{kg}^{-1}\right)\end{array}$ & $\begin{array}{c}\text { ATC } \\
\left(B R L \mathrm{~kg}^{-1}\right)\end{array}$ \\
\hline Initial project status & 1.965 & 90.0 & 0.666 & 0.69 & 6.37 \\
\hline Shorter production cycle (9.5 months) & 1.965 & 90.0 & 0.666 & 0.65 & 6.27 \\
\hline Selectively bred family in third generation & 2.338 & 90.0 & 0.789 & 0.58 & 6.05 \\
\hline
\end{tabular}

than those of family A, we tested for the effect of a reduction of 15 days in the production cycle $(9.5$ months instead of 10 months), which resulted in a $5 \%$ decrease in the average fixed cost and a $2 \%$ reduction in the total production cost for family B (Table 3).

Our results also showed that family B attained an average final weight $19 \%$ higher than the average of F1 families analyzed by Marcos et al. (2016). Thus, we tested a projected $19 \%$ increase in the final weight of a third generation (F3) of tambaqui selectively bred for weight gain, which allowed a $15 \%$ reduction in average fixed costs and a 5\% reduction in total average production costs (Table 3 ).

\section{DISCUSSION}

The oscillation of dissolved oxygen is a common occurrence in semi-intensive systems with low water exchange, due to the concentration of phytoplankton and other nutrients (Ribeiro 2001). Although the oxygen concentration in our pond in some months was below the level considered adequate for tropical fish (5.0 $\mathrm{mg} \mathrm{L}^{-1}$ ) (Boyd 1998), the fish biomass used was lower than that recommended for semi-intensive rearing systems $\left(1 \mathrm{~kg} \mathrm{~m}^{-2}\right)$ (Lima 2013), therefore the necessary level of dissolved oxygen was also lower.

Our F2 tambaqui showed better performance than the 6.29 to $9.06 \mathrm{~g} \mathrm{day}^{-1}$ reported by Marcos et al. (2016) for tambaqui of different families from the F1 generation of the Aquabrasil project, that were cultivated in similar conditions, for 264 days, in a semi-intensive system. In our study, in the hotter months, when the water temperature was higher than $28^{\circ} \mathrm{C}$, the lowest DWG was $7.92 \mathrm{~g} \mathrm{day}^{-1}$ for family A, which is up to $70 \%$ higher than that obtained for non-selectively bred tambaqui ( 4.41 to $4.86 \mathrm{~g} \mathrm{day}^{-1}$ ) cultivated in water with average temperature of $28{ }^{\circ} \mathrm{C}$ (Fernandes et al. 2010).

Although the genetic value of the fish from family $\mathrm{B}$ was not markedly different from that of family A, the performance variables in our trial resulted in measurable differences in production costs between the families. For the selectively bred F1 families of the Aquabrasil Project, an average 14.8\% higher weight gain was observed relative to the control group (non-selectively bred), reaching up to $24.8 \%$ in some families (Marcos et al. 2016). This indicates that selection for weight gain in tambaqui can be enhanced due to the additive genetic values derived directly from the parents. Unlike heterosis, which may provide greater weight gain, but is limited to one generation, breeding programs aim at gains throughout generations (Ponzoni et al. 2005; Nguyen 2016). The average weight gain of the F1 of tambaqui selectively bred for weight gain over 264 days was $1651.5 \mathrm{~g}$ (Marcos et al. 2016), while in our F2, weight gain over a similar period was $1737.5 \mathrm{~g}$ (family A) and $1786.7 \mathrm{~g}$ (family B), an improvement of approximately $7 \%$ over the $\mathrm{F} 1$ performance.

Apparent feed conversion ratio in our study was similar to that reported for tambaqui and its hybrids in large-scale fish farming (Barros and Martins 2012) and for tambaqui fed diets supplemented with the immunostimulant $\beta$-glucan (Chagas et al. 2013). Thus, using selectively bred tambaqui may allow for a reduction of feeding costs, since the fish showed superior weight gain in comparison to that reported in previous studies using non-selected tambaqui (Fernandes et al. 2010; Souza et al. 2014). Reducing feeding costs is a measure of fundamental importance, as this item accounts for the largest share of variable costs in fish production with different species and production systems (Olasunkanmi and Yusuf 2014; Barros et al. 2020; Brabo et al. 2017; Leonardo et al. 2018; Brande et al. 2019; this study).

Survival rate for both families A and B in our study were in accordance with those reported in other studies involving tambaqui and other round fish aquaculture in different production systems (Souza et al. 2014; Brande et al. 2019; Barros et al. 2020).

The significant difference between the families regarding some of the morphometric variables (total length, standard length, body height and body circumference) agrees with the observations made by Marcos et al. (2016) for the F1 generation of these tambaqui. This was expected, since morphometric characteristics determine body shape, which is related to differential muscle mass accumulation in some points of the body, which, in turn, influences body weight and filet yield in fish (Turra et al. 2010). Body form, as well as differences in the size of cultivated fish, should be taken into account for performance evaluation in industrial processing (Lima et al. 2018).

The total production cost per kilogram of fish can be reduced by either obtaining better production performance 
indices or by reducing the animal's rearing cycle by attaining slaughter weight earlier (Barros et al. 2010). The sensitivity analysis showed us that lower production costs and higher weight gain can be achieved, which in turn may render tambaqui less costly to the consumer and/or provide greater profitability to producers, with shorter production costs and greater turnover of invested capital, making aquaculture of native species more efficient. This ultimately renders the activity more economically efficient, with more productive animals.

Our results suggest that the productivity of tambaqui selectively bred for weight gain may further increase over the next generations and significantly benefit productivity and profitability in the tambaqui production system, expanding the accessibility of the product to the final consumer. The continuity of tambaqui breeding programs in Brazil is important, including studies on production performance of tambaqui families, as they provide information on the genetic parameters of the selected animals.

\section{CONCLUSIONS}

Significant differences were detected in morphometric growth and production performance between two tambaqui (Colossoma macropomum) families of the second generation selectively bred for weight gain reared in a semi-intensive system. The better-performing family had a measurably lower production cost, with $4 \%$ lower average fixed costs and $1 \%$ lower total production costs. Sensitivity analysis indicated that even better economic indicators can be achieved for the betterperforming family by allowing a shorter production cycle.

\section{ACKNOWLEDGMENTS}

This study was financed in part by Coordenação de Aperfeiçoamento de Pessoal de Nível Superior (CAPES), Brazil - Finance Code 001 (fellowship); Conselho Nacional de Desenvolvimento Científico e Tecnológico (CNPq) (grants no. 447465/2014-7 and no. 307486/2015-0); Universidade Federal de Mato Grosso (UFMT); VB Alimentos (Jaciara, Mato Grosso, Brazil); and Delicious Fish farm.

\section{REFERENCES}

Barros, A.F.; Martins, M.I.E.G.; Abreu, J.S.; Amaral, C.M.C. 2010. Investimento com Implantação e Custo de Produção em Pisciculturas no Estado de Mato Grosso. 1st ed. UNEMAT, Cáceres, 87p.

Barros, A.F; Martins; M.E.G. 2012. Performance and economic indicators of a large-scale fish farming in Mato Grosso, Brazil. Revista Brasileira de Zootecnia, 41: 1325-1331.

Barros, A.F.; Limberger, D.R.L.; Silva, A.C.C.; Santo, P.R.J.; Santos, V.O.; Santos, I.S. 2020. Custo de implantação, planejamento zootécnico e econômico de pisciculturas de pequeno porte. Brazilian Journal of Development, 6: 27545-27564.
Brabo, M.F.; Natividade Júnior, L.S.; Dias, C.L.; Barbosa, J.; Campelo, D.A.V.; Veras, G.C. 2017. Viabilidade econômica da produção familiar de tambaqui em gaiolas flutuantes no Oeste paraense, Amazônia, Brasil. Custo e Agronegócios online, 13: 275-293.

Brande, M.R.; Leonardo, A.F.G.; Gaona, C.A.P.; Reis Neto, R.V.; Bueno, G.W. 2019. Viabilidade bioeconômica de pisciculturas familiares produtoras de pacu (Piaractus mesopotamicus) em área de Mata Atlântica em São Paulo, Brasil. Custos e Agronegócio online, 15: 2-18.

Boyd, C.E. 1998. Water quality for pond aquaculture. Research and Development Series nr. 43, International Center for Aquaculture and Aquatic Environment, Auburn University, Auburn, 39p.

Chagas, E.C.; Pilarski, F.; Sakabe, R.; Moraes, F.R. 2013. Desempenho produtivo e respostas fisiopatológicas de tambaquis alimentados com ração suplementada com $\beta$-glucano. Pesquisa Agropecuária Brasileira, 48: 899-905.

Emerson, K.; Russo, R.C.; Lund, R.E.; Thurston, R.V. 1975. Aqueous ammonia equilibrium calculations: Effect of $\mathrm{pH}$ and temperature. Journal of the Fisheries Research Board of the Canada, 32: 2379-2383.

FAO. 2018. The State of the World Fisheries and Aquaculture. Food and Agriculture Organization of the United Nations. (http://www. fao.org/3/i9540en/I9540EN.pdf). Accessed on 20 Feb 2019.

Fernandes, T.R.C.; Doria, C.R.C.; Menezes, J.T.B. 2010. Características de carcaça e parâmetros de desempenho do tambaqui (Colossoma macropomum, CUVIER, 1818) em diferentes tempos de cultivo e alimentado com raçóes comerciais. Boletim do Instituto de Pesca, 36: 45-52.

Gomes, L.C.; Simôes, L.N.; Araújo-Lima, C.A.R.M. 2018. Tambaqui (Colossoma macropomum). In: Baldisserotto, B.; Gomes, L.C. (Ed.). Espécies Nativas para Piscicultura no Brasil. 2nd ed. Editora da UFSM, Santa Maria, p.165-204.

Hamby, D.M. 1994. A review of techniques for parameter sensitivity analysis of environmental models. Environmental Monitoring and Assessment, 32: 135-154.

Hilsforf, A.V.S.; Orfão, L.H. 2011. Aspectos gerais do melhoramento genético em peixes no Brasil. Revista Brasileira de Zootecnia, 40: 317-324.

IBGE. 2020. Instituto Brasileiro de Geografia e Estatística. Produção Pecuária Municipal. (https://sidra.ibge.gov.br/tabela/3940). Accessed on 11 Feb 2020.

IMEA. 2014. Instituto Mato-Grossense de Economia Agropecuária. Diagnóstico da Piscicultura em Mato Grosso. (http://www. imea.com.br/imea-site/view/uploads/estudos-customizados/ DiagnosticoPiscicultura.pdf). Accessed on 05 Mar 2020.

Inoue, L.A.K.A.; Boijink, C.L.; Ribeiro, P.T.; Silva, A.M.D.; Affonso, E.G. 2011. Avaliação de respostas metabólicas do tambaqui exposto ao eugenol em banhos anestésicos. Acta Amazonica, 42: 327-342.

Leonardo, A.F.; Baccarin, A.E.; Scorvo Filho, J.D.; Scorvo, C.M.D.F. 2018. Custo de produção da Tilápia-do-Nilo (Oreochromis niloticus) e do pacu (Piaractus mesopotamicus) no Vale do Ribeira, estado de São Paulo. Informaçóes Econômicas, 48: 21-33. 
Lima, A.F. 2013. Sistemas de produção de peixes. In: Rodrigues, A.P.O.; Lima, A.F.; Alves, A.L.; Rosa, D.K.; Torati, L.S.; Santos, V.R.V. (Ed). Piscicultura de Água Doce: Multiplicando Conhecimentos. Embrapa Pesca e Aquicultura, Palmas, p.97-108.

Lima, L.K.F.; Noleto, S.S.; Santos, V.R.V.; Luiz, D.B.; Kirschnik, P.G. 2018. Rendimento e composição centesimal do tambaqui (Colossoma macropomum) por diferentes cortes e categorias de peso. Revista Brasileira de Higiene e Sanidade Animal, 12: 223-235.

Marcos, R.; Povh, J.A.; Fornari, D.C.; Oliveira, C.A.L.; Ribeiro, R.P.; Lopera Barrero, N.M.; et al. 2016. Weight gain and morphometric growth of genetically improved tambaqui (Colossoma macropomum). Semina: Ciências Agrárias, 37: 25212528.

Martin, N.B.; Serra, R.; Oliveira, M.D.M.; Ângelo, J.A.; Okawa, H. 1998. Sistema integrado de custos agropecuários-Custagri. Informaçôes Econômicas, 28: 8-28.

Menezes, A. 2005. Aqüicultura na prática; peixes, camarôes, ostras, mexilhöes e sururus. 1st ed. Hoper, Espírito Santo, 107p.

Nguyen, N.H. 2016. Genetic improvement for important farmed aquaculture species with a reference to carp, tilapia and prawns in Asia: achievements, lessons and challenges. Fish and Fisheries, 17: 483-506.

Oliveira, C.A.L.; Ribeiro, R.P.; Streit Junior, D.P.; Povh, J.A.; Resende, E.K. 2012. Melhoramento genético de peixes, uma realidade para a piscicultura brasileira. Panorama da Aquicultura, 22: $38-47$.

Ponzoni, R.W.; Hamzah, A.; Tan, S.; Kamaruzzaman, N. 2005. Genetic paramaters and response for live weight in the GIFT strain of Nile tilapia (Oreochromis niloticus). Aquaculture, 247: 203-210
Resende, E.K. 2009. Pesquisa em rede em aquicultura: bases tecnológicas para o desenvolvimento sustentável da aquicultura no Brasil. Aquabrasil. Revista Brasileira de Zootecnia, 38: 52-57.

Ribeiro, R.P. 2001. Ambiente e água para piscicultura. In: Moreira, H.L.M.; Vargas, L.; Ribeiro, R.P.; Zimmermann, S. (Ed.). Fundamentos da Moderna Aquicultura. 1st ed. Editora ULBRA, Canoas, p.37-43

Olasunkanmi, N.O.; Yusuf, O. 2014. Resource use efficiency in small scale catfish farming in Osun State, Nigeria. Sky Journal of Agricultural Research, 3: 37-45.

Sabbag, O.B.; Takahashi, L.S.; Silveira, A.N.; Aranha, A.S. 2011. Custos e viabilidade econômica da produçáo de lambari-do-raboamarelo em Monte Castelo/SP: um estudo de caso. Boletim do Instituto de Pesca, 37: 307-315.

Souza, R.A.; Padua, D.M.C.; Oliveira, R.P.C.; Maia, T.C.B. 2014. Análise econômica da criação de tambaqui em tanques-rede: estudo de caso em assentamento da reforma agrária. Custo e Agronegócios online, 10: 253-268.

Silva, G.F.; Shiotsuki, L.; Teixeira, R.A.; Dias, L.T.; Villela, L.C.V.; Freitas, L.E.L.; et al. 2018. Programas de Melhoramento Genético na Piscicultura. Documentos no. 37, EMBRAPA Pesca e Aquicultura, Palmas, 64p.

Turra, E.M.; Oliveira, D.A.A.; Teixeira, E.A.; Prado, S.A.; Melo, D.C.; Souza, A.B. 2010. Uso de medidas morfométricas no melhoramento genético do rendimento de filé da tilápia do Nilo (Oreochromis niloticus). Revista Brasileira de Reprodução Animal, 34: 29-36.

Woynarovich, E.; Horváth L. 1980. The Artificial Propagation of Warm-water Finfishes: a Manual for Extension. FAO Fisheries Technical Paper nr. 201, 183p.

RECEIVED: $14 / 06 / 2019$

ACCEPTED: 06/05/2020

ASSOCIATE EDITOR: Rodrigo del Valle 